\title{
Sustainable Food Processing Instrument (i-KProM) among Technical and Vocational Education Training (TVET) Students
}

Rafidah Abu Nasir, Suriani Mohamed

To Link this Article: http://dx.doi.org/10.6007/IJARBSS/v11-i4/9713

DOI:10.6007/IJARBSS/v11-i4/9713

Received: 01 February 2021, Revised: 06 March 2021, Accepted: 28 March 2021

Published Online: 22 April 2021

In-Text Citation: (Nasir \& Mohamed, 2021)

To Cite this Article: Nasir, R. A., \& Mohamed, S. (2021). Sustainable Food Processing Instrument (i-KProM) among Technical and Vocational Education Training (TVET) Students. International Journal of Academic Research in Business and Social Sciences, 11(4), 656-674.

Copyright: @ 2021 The Author(s)

Published by Human Resource Management Academic Research Society (www.hrmars.com)

This article is published under the Creative Commons Attribution (CC BY 4.0) license. Anyone may reproduce, distribute, translate and create derivative works of this article (for both commercial and non-commercial purposes), subject to full attribution to the original publication and authors. The full terms of this license may be seen at: http://creativecommons.org/licences/by/4.0/legalcode

Vol. 11, No. 4, 2021, Pg. 656 - 674

Full Terms \& Conditions of access and use can be found at http://hrmars.com/index.php/pages/detail/publication-ethics 


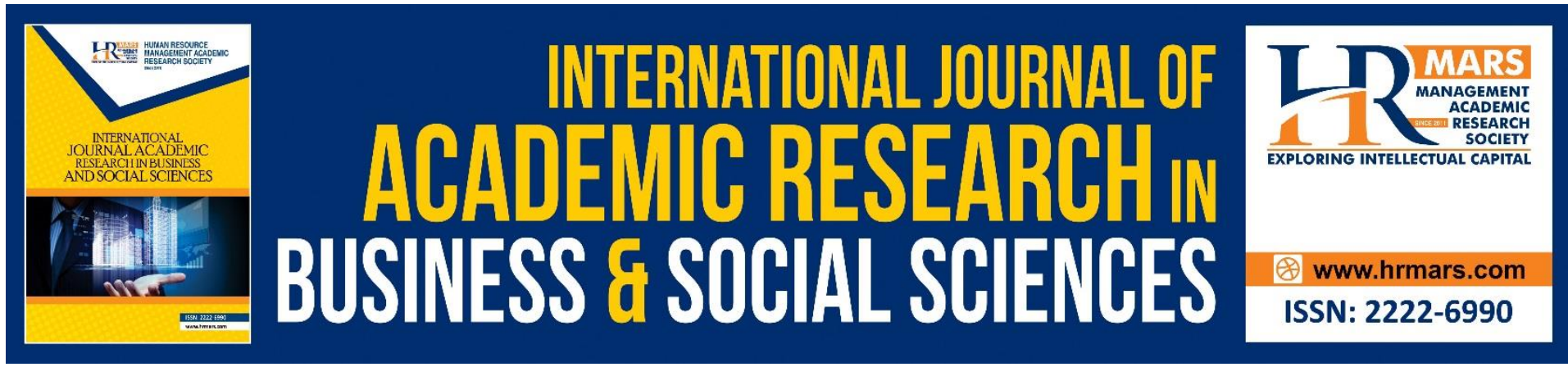

\title{
Sustainable Food Processing Instrument (i- KProM) among Technical and Vocational Education Training (TVET) Students
}

\author{
Rafidah Abu Nasir, Suriani Mohamed \\ Faculty of Technical and Vocational, Universiti Pendidikan Sultan Idris Malaysia \\ Email: rafidahabunasir@gmail.com
}

\begin{abstract}
The depletion of natural resources and increasing food consumption together with their food waste showing the urge to practice the sustainable food processing. The instrument of sustainable food processing (i-KProM) questionnaire was used to determine the right practices constructs for TVET students' in sustainable food processing and the related predictive factor. This study was conducted in TVET institutional in Perak which offering the Certification of Food Processing and Quality Control. An Exploratory Factor Analysis (EFA) for validity test and reliability test was used to measure the instrument and give an empirical verification of the construct validity and reliability of the questionnaire. Literature search and pilot study within the population were carried out and appropriate item was extracted. Initially, 37 items developed for sustainable food processing practices, however, only 23 items were remaining as an item investigate and 14 items found as not sufficient as required for EFA. For an independent variable of the research, 36 items remain which include five factors extracted. The sustainable food processing instrument (i-KProM) have been approved to have sufficient validity and reliability.
\end{abstract}

Keywords: Sustainable Food Processing, Exploratory Factor Analysis, Technical and Vocational Training.

\section{Introduction}

Technical and vocational education and training are an education towards decent jobs and occupation (UNESCO, 2016). Incheon Declaration 2015 has specified target in technical and vocational education training (TVET) to achieve 4th Sustainable Development Goal, which ensure women and men get equal access, affordable and quality of TVET in tertiary education including in universities (Sustainable Development Goals, SDG, 2030). This tertiary education plays the vital role for increasing the mobility of trainer and learners to enhance an academic credentials.

In supporting tertiary education of TVET, The Eleventh Malaysia Plan 2016-2020 projected that $60 \%$ of future job require TVET related skill to lead the country economic growth. To ensure the success of the projection, there are seven areas of TVET standard being listed which is; programme development and delivery, assessment of students' learning, 
student selection and support services, teaching staff, educational resources, program management and program monitoring, review and continual improvement (Malaysian Qualification Agency, 2019). In line with its vision and mission, Jabatan Pendidikan Politeknik \& Komuniti Komuniti (JPPKK) has published TVET 4.0 Framework outlines to contribute directly to the sustainability of development in the current education sector, where TVET graduates will be future leaders and industry players in their related fields (Jabatan Pendidikan Politeknik \& Komuniti, Oktober 2018; Aziz, Musa \& Rashid, 2019).

Studies related to sustainable development in the context of education in Malaysia are widely published (Mahat et al., 2019; Omar et al., 2019; Raman \& Abu Bakar, 2019; Retno et al., 2019). As a part of sustainable development, sustainable consumption and production (SCP) playing the vital role to ensure food security of the urbanized world (Knorr et al., 2020). SCP as discussed in Oslo Symposium is the improvement of products or services to improve the quality of life by minimizing the use of natural resources and toxic materials, while reducing waste and pollution risk, to ensure the needs of future generations (Ofstad et al., 1994). It should be safe and beneficial to employees and the consumer community as well as benefit the entire cycle involved (Ali \& Suleiman, 2016; Tseng \& Divinagracia, 2009). In the context of food, food processing is done to prolong the shelf life of food, optimize the nutrition and quality of food as well as reduce food spoilage and waste (Augustin et al., 2016). Processing can also reduce food waste due to damage, loss of freshness and quality by extending the shelf life (Martindale \& Schiebel, 2017).

Meanwhile Alders et al., (2018) reported that the current food system is facing major problem which will give severe impact on human well-being during the Food Security Workshop in Sydney. Therefore, the members of the workshop agree to adopt the sustainability of the food system to ensure the food security being address accordingly. The food processing activities require deep attention from authority and educators to investigate the sustainability along the programme that being offered (Reza, 2016) and should be include in TVET fields. However, the adaptation of the sustainability in the current education and curricular are still far behind the requirement all over the world (Etse \& Ingley, 2015; Paryono, 2017; Chin et al., 2019).

The threat of food security discussed above require for changes of food system to a more ethical, safe and nutritious processing from individually or by the authorities (Alders et al., 2018). The issue of food in terms of its intake and processing, requires a change including changes in food processing from the aspect of its effectiveness unit, starting from the food produced (Garnett, 2013). Statement by Alders et al. (2018) and Garnett (2013) illustrate that, existing food processing areas have sustainability issues that need to be addressed. An irresponsible sustainability practices (Taufique et al., 2016) as well as lack of planning and management of food processing are major problems of waste generation as expressed through expert views in a study by Aschemann (2015). This current study offers a new contribution in critical sustainable food processing practices aspects, which have huge results in the industry but limited in TVET and education. The need for training to improve knowledge, attitudes and practices of food waste management and its reduction rate is very much needed in the field of food processing (Okumus, 2019; Gunders \& Bloom, 2017: Gössling et al., 2011). 
Therefore, this study is to investigate the predictive factor towards the sustainable food processing practices among the TVET student as they are less competent in the technical skills required by the industry (Rus et.al 2015). The predictive factors suggested are knowledge, awareness, attitude, subjective norm, perceived behavioural control and personal norm. The relationship between knowledge, attitudes and practices is discussed in Theory of Planned Behaviour (TPB) by Icek Ajzen (1991) which also include that the belief that a person who thinks they have a high chance and resource to perform the related action the higher the behaviour control action within themselves on that behaviour (Madden, Ellen \& Ajzen, 1992).

Introduced by Ramsey and Rickson, (1976), study on behaviour seem very important for sustainable development, as several studies have been conducted using the Knowledge Attitude and Practices Model(Besar et al., 2013; Ahmad et al., 2011; Derahim., 2011 \& SalasZapata et al., 2018). However, some research argued that practices not necessarily influenced by knowledge and attitudes, there are other factors that need to be considered (Kollmuss \& Agyemen, 2002). Some research mentioned that only attitudes have a significant influence on individual practices (Sayuti, 2020), while knowledge does not affect individuals to behave unless they need to be implemented at the appropriate time, subject to subjective norms and their environment (Greyson \& Johnson, 2016).

Futhermore, according to Hungerford and Volk (1990) in Model of Predictors of Environmental Behaviour (PEB), having knowledge of an environmental issue, will not have a positive impact on behaviour that is responsible for sustainability as a whole. There are various internal and external factors that influence the practice of responsibility for sustainability, including barriers, social stress and the opportunity to choose different actions that can restrict or influence a person to act (Ruolin \& Nicolette, 2020 \& Ungerer, 2015). According to Kollmuss and Agyeman (2002), the practice of sustainability can only be done when it is normalized to become a habit through their experiences that lead to environmental sustainability, which will also affect the subjective norms, perceived behavioural control as well as the personal norms of the individual. In addition, fostering attitude and effectiveness of awareness also has a significant impact on pro-environmental behaviour (Ramly et al., 2012).

Therefore, this study is to investigate an empirical verification of the construct validity and reliability of the questionnaire for sustainable food processing practices in community college. The results of these findings can be a guideline and suggestions for the start of a new curriculum design that applies the concept of sustainability. Without an education for sustainable development, it is difficult to make Malaysia a country that is moving towards sustainable development. The need to determine the sustainability of food processing practices is seen as very significant because studies on it are still limited (Ali \& Suleiman, 2016).

Accordingly, the objectives of this paper are: (1) To determine the construct validity of sustainable food processing practices by using Exploratory Factor Analysis; and (2) To obtain the reliability of i-KProM questionnaires. The i-KProM items, methodology, data analysis, findings and conclusion will be discussed to achieve the objectives of this paper. 


\section{Methodology}

This study takes place in community colleges in Perak with a population of 808 students.The related community colleges selected due to higher numbers of students to fulfilled the requirement of exploratory factor analysis with the minimum five times of the variables involved in any study (Pallant, 2016). There are 104 completed questionnaires received from students enrolled for Certificate of Food Processing and Quality Control from the selected community colleges which have been approved by Jabatan Pendidikan Politeknik dan Kolej Komuniti as the sampling plan for this research.

The $\mathrm{i}-\mathrm{KPrOM}$ is an instrument which analysed the content validity and reliability during the pre-test study. This $\mathrm{i}-\mathrm{KP}$ roM is suitable to be used to measure predictive factors for sustainable food processing practices among the TVET students in community colleges (Nasir, 2020). However, due to the large number of variables and items have been developed, this study is aimed to explore the interrelationship among the set of variables which mean to investigate any variables in the set form coherent subsets that are relatively independent of one another (Tabachnick \& Fidell, 2013).

Data collection had been administered using Google forms that specify each item must be answered to allow respondents to complete the given questionnaire. This online questionnaire is more effective and facilitates data management (Wahyudi, Warijan \& Suyanta, 2020). Although there are some studies finding that the response rate for online surveys is low (Fincham, 2008; Sitzia \& Wood, 1998), but the ability of respondents to answer the questionnaire in their own time can guarantee a higher response rate than conventional methods (Ball, 2019 and Callegaro et al., 2015) especially as this study was administered during the covid-19 pandemic situation.

Tuten (2010) has listed several advantages of conducting online research among them are; the work for data transcription is easier because all the data is recorded electronically, the response to the questionnaires will be more detailed and clear than by survey using printed forms. Even surveys involving practices and attitudes will be more accurate because respondents are more honest in the responses given due to their awareness of not being recognized if answering questionnaires online (Tuten, 2010).

The i-KProM was developed using the Good Manufacturing Practices code guided by Ministry of Health Malaysia. The questionnaire consist of 4 section, A: demographic chacacteristic, B: sustainable food processing practices C: predictive factor (knowledge $=28$ items) and D: other predictive factors (awareness $=10$ items, attitude $=15$ items, subjective norm $=4$ items, perceived behavioural control $=7$ items and personal norm $=4$ items).

Section A consisted of three personal information (gender, community college and semester) where respondent must choose any characteristic that represent themselves. The second part consisted of 37 items regarding the frequency of sustainable food processing practices with the likert scale $1=$ Never; $2=$ Seldom; $3=$ Sometimes; $4=$ Often; $5=$ Very often. The third section consisted of knowledge item for predictive factor variables with likert scale 1=True; $2=$ False. However, this section was not included in this study as the scale using are not comply with factor analysis requirement. Section $D$ consisted of five likert scale which represented as 1= Very Disagree, 2= Disagree, 3= Fairly Disagree, 4= Agree and 5= Strongly 
agree. The respondent needs to choose which scale represent their agreement toward the statement provided.

The main objective of this study is to determine the construct validity for sustainable food processing and the correctness of the items and the inner structure of the construct measure of the instrument. To obtain the idea of this study, Exploratory Factor Analysis (EFA) was conducted to examine the structure of the scale for construct validity and followed by the reliability analysis to test the reliability of the final questionnaire after the EFA being analysed.

For this purpose, normality tests are performed to obtain the pattern of data distribution. According to Hair et al., (2006), good data is data that has a normal distribution. The data of this study have been analysed using the normality test (kurtosis and skewness) before an EFA being run as recommended by Kline (2005). An application of IBMSPSS version 26 was used to analysis the test mentioned above.

A construct validity is to determine the constructs of the instrument developed is able to measure what it should be measured, where the accuracy and usability of the built instrument can be inferred into the actual study later (Kline, 2005: Ahmad Hashim, 2004). The construct validity used in this study is a factor analysis procedure on all items in each construct of dependent variables and independent variables. Factor analysis is a statistical technique that allows interested researchers to know the variables that form a subset independently of each other. This means, the combination of variables that correlate with each other, forming a factor that is partially independent of the subset of other variables (Tabachnick \& Fidell, 2013). Factor analysis procedures aim to analyze the relationship between multiple variables (Hair et al., 2006). The purpose of the exploratory factor analysis procedure conducted in this study is to determine the position factor of each measurement item (Hair et al., 2006). According to Pett, Lackey and Sullivan (2003) for the purpose of evaluating the validity structure of good internal constructs for a particular population, factor analysis procedures can be performed to identify external variables of the study.

Reliability analysis is to obtain a similar score of the measurement that performed repeatedly using the same instrument to test an item or construct (Cavana, Delahaye \& Sekaran, 2001). They also suggested that, there are four methods of measuring reliability, namely test-retest, parallel-form, split-half and internal consistency.

Construct validity using factor analysis procedures can be implemented if the data obtained meet the required statistical assumptions. Pallant (2016) discusses the assumptions that need to be met are: first, the overall sample size should be at least five times the number of variables selected as stated by Tabachnick and Fidell (2013). For the purpose of this study, a total of 10 constructs represented by four sub-constructs for the dependent variables and six independent variables were used.

The second assumption to fulfill in this study is the value of the correlation matrix should exceed 0.30, whereas the value of Bartletts' test of Sphericity should be significant, $p$ $<0.05$, followed by the Kaiser-Meyer-Olkin (KMO) value should exceed 0.60 which can be obtained in the findings of factor analysis conducted to prove items correlated with each 
other. Next assumption is, the data obtained need to have linearity because factor analysis is to see the correlation between the variables that are assumed to have a linear relationship. Finally, the value of outliers needs to be considered by the researcher because factor analysis is not suitable for variables that have extreme data where the researcher needs to review the data to determine whether the data needs to be discarded or re-coded. However, there are few opinions suggested that the normality of distributions is not very critical to determine if the researcher needs to explore, summarize and explain the relationship between the variables studied which most likely related to this study (Hair et al., 1995; Pett et al., 2003; and Tabachnick \& Fidell, 2013).

\section{Results and Discussion}

\section{Validity Analysis Using Exploratory Factor Analysis}

Regarding to current study by considering that the above basic assumptions have been met, the following three main steps have been carried out to test the intended factor analysis procedure. Firstly, the sample size was 104 which is ten times compared to the 10 variables selected for this study. The correlation matrix value was determined to have a value greater than 0.30 using the value generated by SPSS, while to assess the factoring data, Bartlett's test of sphericity was significant $(p<.05)$ at 0.01 , as well as Kaiser-Meyer-Olkin ( KMO) is 0.70 where, according to Tabachnick \& Fidell (2001) values above 0.6 are the minimum values for conducting good factor analysis.

The second step is to obtain the smallest number of factors to represent the selected variables to explain the variance values of the original data set. (Pallant, 2016). Therefore, the researcher had explored with a number of different factors to obtain the most appropriate number of factors in this study as suggested by Tabachnick \& Fidell (2013). The determination to select the number of factors for this factor analysis is based on three aspects; first, Kaiser's Criterion which is a factor with an eigenvalue value exceeding 2.0 according to the recommendations of Tabachnick \& Fidell (2007) will be proposed as a number of factors, secondly by looking at the plot on the Catell scree test (Catell, 1966) where the points before the plot forming an elbow proposed to be the number of factor and thirdly a parallel analysis in which the value of eigenvalue which exceeds the test value of the analysis will be set as the actual number of factors.

The third step in determining factor analysis is to interpret by making rotation through two approaches namely orthogonal or obligue. Since the items for the food sustainability practice construct are items that refer to Good Food Manufacturing Practices, GMP 2018, Ministry of Health Malaysia, then the researcher assumes that the items constructed are independent of each other. Thus, rotation using the orthogonal varimax method is used to determine the total number of factors for this study as suggested by Gorsuch (1983) and supported by Brown (2009).

\section{Sustainable Food Processing Practices}

The sustainable food processing practices variable questionnaire consists of 37 items have been analyzed using factor analysis in terms of; (a) acquisition and storage of raw materials, (b) production of products and sanitation, (c) packaging and use of products; and (d) management of waste disposal. Based on the analysis conducted, the KMO value is 0.67 above 0.60 as suggested and Barlett's test of sphericity (Barlett, 1954) is significant at $p<0.01$ with the estimated value of Chi-Square 811.665 at degree 253 showing items correlated with each other. Communilities value is above 0.30 . The finding above indicates the appropriate 
data matrix for factor analysis.

Factor analysis through the Varimax rotation procedure, on the Rotated Component Matrix table shows the items of the three-dimensional questionnaire (contains 3 factors). Therefore, Table 1 showed the three factors have been extracted as suggested by Tabachnick \& Fidell (2007) which is a factor with an eigenvalue value that exceeds two, is a good factor for a study in addition to the evaluation of the Scree Plot. All three factors predict a total of 41.05 percent variance for the dependent variables of food processing sustainability practices. Examination of the items under each factor with reference to previous studies on the boundaries of sustainable food processing practices proposed by Holden and Yan (2014) that the key aspects in food processing are; processing (12 items), post-processing (6 items) and pre-processing (5 items) for this questionnaire. 
Table 1: Summary of EFA for Sustainable Food Processing Practices variables

\begin{tabular}{llll}
\hline Item Code & 1 & 2 & 3 \\
\hline
\end{tabular}

\section{FACTOR 1 Processing}

AC2 Packing end products using plastic wrap. $\quad .799$

AC4 Provide end products to others if excessive. $\quad .687$

Store the product in a recyclable container $\quad .649$

AC6 (recycle).

AB15 Wash used aprons / labcoats. $\quad 609$

Use the same wipes cloth to wipe tables and $\quad .606$

AB8 utensils.

AB16 Wipe the equipment with a rag after lab activities. .588 Put the product into the container / packaging $\quad .570$

AC3 immediately after processing.

Cut the fruit as much as possible to reduce the $\quad .556$

AD7 waste to be discarded.

Cleaning the worktable after food processing $\quad .509$

AD8 activities.

AB5 Wear a mask during food processing activities. $\quad .479$

AD1 Separate the waste before throwing it in the trash. .429 Wear a hat (Male / Non-Muslim) or hijab (Female) .425

AB13 during food processing activities.

\section{FAKTOR 2 Post-processing}

AD3 Dispose of glass trash in a brown trash can. $\quad .776$

Store the raw material in a container with an $\quad .660$

AA6 expiration date.

Store food grade chemicals in the same place as $\quad .651$

AA5 dry raw materials.

Collect practical waste to make organic fertilizer. $\quad .623$

AD5 (examples: eggshells, fruit skins)

AB1 Discard raw materials if weighed incorrectly. ${ }^{*} \quad .599$

AD4 Throw paper type trash into a blue trash can. $\quad-.514$

\section{FAKTOR 3 Pre-processing}

Wear accessories (watches / jewelry) during food $\quad .700$

AB14 processing activities.

Separate cold raw materials (chill) and frozen raw $\quad .675$

AA3 materials (frozen) during storage.

Place end products on the floor before stacking on

AC5 shelves.

Do not mind using slightly dented canned raw $\quad .503$

AB9 materials.

Steaming glass bottles for sterilization of chili

AC1 sauce bottles. 


\begin{tabular}{ll}
\hline Eigenvalues & 7.3373 .5743 .140 \\
Varians Percentage & 19.839 .6608 .485 \\
KMO & 1 \\
BTOS Test & .694 \\
df & 1765. \\
Sig. & 06 \\
& 666 \\
& .000 \\
\hline
\end{tabular}

The results of the analysis also show that there are 12 items that overlap the concept where those items were removed for the purpose of this study.

\section{Awareness}

The independents variables for awareness consisted 10 items and the test results found that the KMO value was 0.92, exceeding the set value of 0.6 and the value of Barlett's test of sphericity (Barlett, 1954) was significant at $p<0.01$ with an estimated value of Chi-Square 636.81 at degree 45 shows the items in these variables correlated with each other. In addition, the value of communilities is more than 0.3. The MSA (Measure of Sampling Adequacy) value for items individually ranging from 0.39-0.72 also indicates appropriate for factor analysis. Factor analysis only produces one factor which is awareness. The factor load for the item in this factor is between 0.624 to 0.846 . The overall variance contribution value was 59.75 percent with the eigenvalues value of 5.98 . The results of the observations in the anti-image matrix correlation suggest that all factors have a sufficient load, so no factor is dropped. Table Table 2 below shows the summary of factor analysis conducted.

Table 2: Summary of EFA for Independent Variables Awareness

\begin{tabular}{clc} 
Code & \multicolumn{1}{c}{ Item } & Factor Loading \\
\hline FK1 & $\begin{array}{l}\text { Quality products are a necessity for every household. } \\
\text { Good storage can guarantee the supply and quality } \\
\text { of food products. }\end{array}$ & .725 \\
FK3 & $\begin{array}{l}\text { I need to produce nutritious products that guarantee } \\
\text { the country's food supply. }\end{array}$ & .788 \\
FK4 & $\begin{array}{l}\text { Packaging can facilitate the distribution of food } \\
\text { supplies nationwide. }\end{array}$ & .842 \\
FK5 $\quad \begin{array}{l}\text { I need to replace existing food processing methods, } \\
\text { to increase food productivity. }\end{array}$ & .717 \\
FK6 & $\begin{array}{l}\text { Food management and food processing techniques } \\
\text { are important for food supply assurance. }\end{array}$ & .837 \\
FK7 & $\begin{array}{l}\text { I need to be prepared to participate in food safety } \\
\text { certification program (MESTI). } \\
\text { Climate change affects food security. } \\
\text { I need to participate in activities that contribute to } \\
\text { food security. }\end{array}$ & .624 \\
FK10 & $\begin{array}{l}\text { Sustainable food processing is able to guarantee food } \\
\text { supply. }\end{array}$ & .846
\end{tabular}




\begin{tabular}{lc}
\hline Eigenvalues & 5.975 \\
Varians Percentage & 59.750 \\
KMO & .920 \\
BTOS Test & 636.808 \\
df & 45 \\
Sig. & .000 \\
\hline
\end{tabular}

\section{Attitude}

The measurement scale for the attitude variables contained 15 questionnaire items before 2 items were dropped because they had a value of communilities $<0.3$. The test results found that the KMO value was 0.88 , exceeding the set value of 0.6 and the value of Barlett's test of sphericity (Barlett, 1954) was significant at $p<0.01$ with the estimated value of Chi-Square 804.38 at degree 105 indicating items in this variable correlate with each other. In addition, the value of communilities gives a value of more than 0.3. The MSA (Measure of Sampling Adequacy) value for individual items ranges from 0.36-0.66 also indicates suitablity for factor analysis. Factor analysis only produces one factor which is attitude. The factor load for the item in this factor is between 0.62 to 0.81 . The overall variance contribution value is 48.00 percent with the eigenvalues value of 7.20. The results of observations in the anti-image matrix correlation suggest that two items do not have sufficient load, so the dropped they have been dropped.

The factor analysis of the validity of the content of the items carried out on the construct of attitude variables and test results is as shown in Table 3 below.

Table 3. Summary of EFA for Independent Variables Attitude

\begin{tabular}{|c|c|c|}
\hline Kod & Item & Factor Loading \\
\hline FS1 & $\begin{array}{l}\text { I think buying local raw materials supports the concept of } \\
\text { sustainability as opposed to giving imported goods. }\end{array}$ & 0.766 \\
\hline FS2 & $\begin{array}{l}\text { I think storing products by category is a sustainable food } \\
\text { processing practice. }\end{array}$ & 0.807 \\
\hline FS4 & $\begin{array}{l}\text { I think labels on raw materials provide information on how to use } \\
\text { the product efficiently. }\end{array}$ & 0.623 \\
\hline FS5 & $\begin{array}{l}\text { I think using the right temperature while processing can save } \\
\text { energy (gas and electricity). }\end{array}$ & 0.611 \\
\hline FS6 & $\begin{array}{l}\text { I think using machines and tools with the right functions can } \\
\text { make the job easier. }\end{array}$ & 0.726 \\
\hline FS7 & $\begin{array}{l}\text { I think properly measured food additives ensure the } \\
\text { sustainability of food processing. }\end{array}$ & 0.740 \\
\hline FS8 & I think, every college should provide space to sell products. & 0.705 \\
\hline FS10 & $\begin{array}{l}\text { I think products that are often not used up should be reduced } \\
\text { production. }\end{array}$ & 0.745 \\
\hline FS11 & $\begin{array}{l}\text { I believe, everyone wants to take advantage of their products } \\
\text { through consumer sustainability education. }\end{array}$ & 0.776 \\
\hline FS12 & I think managing waste well, can reduce solid waste. & 0.792 \\
\hline FS13 & I feel upset if I have to throw away food. & 0.704 \\
\hline FS14 & I think solid waste segregation facilitates cleaning work. & 0.760 \\
\hline FS15 & $\begin{array}{l}\text { I believe, food waste made into organic fertilizer is a good } \\
\text { practice. }\end{array}$ & 0.709 \\
\hline
\end{tabular}




\begin{tabular}{lr}
\hline Eigenvalues & 7.199 \\
Varians Percentage & 47.991 \\
KMO & .884 \\
BTOS Test & 804.379 \\
df & 105 \\
Sig. & .000 \\
\hline
\end{tabular}

\section{Subjective Norm}

The measurement scale for the subjective norm variable consisted of 4 items and the test results found that the KMO value was 0.777 , exceeding the set value of 0.6 and Barlett's test of sphericity (Barlett, 1954) was significant at $p<0.01$ with an estimated Chi-Square value of 175,595 at 6 degree shows that the items in this variable are correlated with each other. In addition, the value of communilities gives a value of more than 0.3. The MSA value for individual items ranged from 0.525-0.749 also indicates suitability for factor analysis. Factor analysis only produces one factor which is subjective norm. The factor load for the item in this factor is between 0.725 to 0.865 . The overall variance contribution value was 68.03 percent with the eigenvalues value of 2.72 . The results of the observations in the anti-image matrix correlation suggest that all factors have sufficient load, therefore no factors are dropped as detailed in Table 4 below.

Table 4. Summary of EFA for Independent Variables Subjective Norm

\begin{tabular}{clc} 
Code & \multicolumn{1}{c}{ Item } & $\begin{array}{c}\text { Factor } \\
\text { Loading }\end{array}$ \\
\hline FNS1 & $\begin{array}{l}\text { My friend encourages the storage of raw materials according to } \\
\text { the category / type of material. } \\
\text { FNS2 }\end{array}$ & .865 \\
& $\begin{array}{l}\text { Lecturers / Employers encourage the storage of raw materials } \\
\text { with the concept of First In, First Out (FIFO). }\end{array}$ & .836 \\
FNS3 & $\begin{array}{l}\text { All my friends want me to wear aprons, headgear and bring rug } \\
\text { cloth during processing practical. }\end{array}$ & .725 \\
FNS4 & $\begin{array}{l}\text { The lecturer insisted that I adhere to Good Manufacturing } \\
\text { Practices (GMP) such as always washing my hands and keeping }\end{array}$ & .865 \\
\hline $\begin{array}{l}\text { Eigenvalues } \\
\text { Varians Percentage }\end{array}$ & \\
KMO & myils short and clean. & 2.721 \\
BTOS Test & 68.030 \\
df & .913 \\
Sig. & 175.595 \\
\hline
\end{tabular}

\section{Perceived Behavioural Control}

The measurement scale for the perceived behavioural control variable consisted of 7 items before the one item was dropped because it had a communilities $<0.3$. After conducting reanalysis, the test results found that the KMO value of 6 items was 0.874 , exceeding the set value of 0.6 and Barlett's test of sphericity (Barlett, 1954) was significant at $p<0.01$ with an estimated value of Chi-Square 263.963 at degree 15 shows the items in these variables correlated with each other. In addition, the communilities value gives a value of more than 0.3. The MSA value for individual items ranging from 0.881-0.901 also indicates suitable for 
factor analysis. Factor analysis produced only one factor, namely the behavioural perception perception factor. The factor load for the item in this factor is between 0.682 to 0.868 . The total variance contribution value is 60.121 percent with a value of eigenvalues of 3,607. Therefore, a total of 6 items were used for the perceived behavioural control factor towards further study as detailed in Table 5 below.

Table 5. Summary of EFA for Independent Variables Perceived Behavioural Control

\begin{tabular}{clc} 
Code & \multicolumn{1}{c}{ Item } & Factor Loading \\
\hline FPK1 & $\begin{array}{l}\text { Lack of emphasis on good raw material storage causes its } \\
\text { implementation to be ineffective. }\end{array}$ & .682 \\
FPK2 & $\begin{array}{l}\text { Hygiene and sanitation practices in food processing can be } \\
\text { done well, when all the equipment and facilities are available } \\
\text { to everyone. }\end{array}$ & .868 \\
FPK3 & $\begin{array}{l}\text { The practical time given is sufficient to ensure the cleanliness } \\
\text { of the equipment and workspace is well made. }\end{array}$ & .792 \\
FPK4 & $\begin{array}{l}\text { The problem of clogged pipes, inadequate sinks complicates } \\
\text { food processing waste management practices. }\end{array}$ & .752 \\
FPK5 & $\begin{array}{l}\text { I need to produce a clean and safe product if I have to bear } \\
\text { the consequences of food poisoning produced. }\end{array}$ & .726 \\
FPK7 & $\begin{array}{l}\text { Cleanliness of equipment and workplace, can be maintained } \\
\text { through the cooperation of everyone. }\end{array}$ & .819 \\
\hline Eigenvalues & 3.607 \\
Varians Percentage & 60.121 \\
KMO & & .874 \\
BTOS Test & 263.963 \\
df & & 15 \\
Sig. & & .000 \\
\hline
\end{tabular}

\section{Personal Norm}

The measurement scale for the personal norm variable contained 4 items of questionnaire before the FNP2 item was dropped because it had a uniformity value (Communilities) <0.3. After conducting re-analysis, the test results found that the KMO value of 3 items is 0.633 above the set value of 0.6 and Barlett's test of sphericity (Barlett, 1954) is significant at $p<0.01$ with an estimated value of Chi-Square 65.92 at degree 6 shows the items in this variable are correlated with each other. In addition, the value of uniformity (Communilities) gives a value of more than 0.3. The MSA (Measure of Sampling Adequacy) value for individual items ranging from $0.45-73$ also indicates suitable for factor analysis. Factor analysis only produces one factor which is personal norms. The factor load for the item in this factor is between 0.545 to 0.705 . The overall variance contribution value is 49.386 percent with the eigenvalues value of 1,975 as shown in Table 3.110 below. Therefore, a total of 3 items was used for the personal norm factor against the actual study. Table 3.21 below shows the summary of factor analysis for personal norm variables. 
Table 6 Summary of EFA for Independent Variables Personal Norm

\begin{tabular}{llr} 
Code & Item & Factor Loading \\
\hline FNP1 & $\begin{array}{l}\text { I feel guilty if the end product is not good quality because I did not } \\
\text { follow the proper practical method. }\end{array}$ \\
FNP3 & $\quad \begin{array}{l}\text { I care about storing chilled raw materials because they are easily } \\
\text { damaged. }\end{array}$ \\
FNP4 & If I value food hygiene, I also value the safety and sustainability of \\
& $\quad$ the general public. & .667 \\
\hline Eigenvalues & .855 \\
Varians Percentage & 1.975 \\
KMO & 49.386 \\
BTOS Test & .633 \\
df & 65.922 \\
Sig & 6 \\
\hline
\end{tabular}

\section{Reliability Analysis}

The current study was using a measurement of internal consistency to determine the reliability coefficient known as Cronbach Alpha for each construct and the entire evaluation instrument through Statistical Package for Social Science (SPSS) version 26.0 software. Cronbach Alpha statistics are calculated from a range of 0 to 1 where the value approaching 1 indicates that the items in the questionnaire have a positive correlation with each other and have a high internal consistency. Cronbach Alpha values less than 0.6 are considered weak and unsatisfactory while values above 0.6 are acceptable or reliable. However, values above 0.8 are considered better (Cavana, Delahaye \& Sekaran, 2001; Hair et. Al., 2007). Jackson (2006) suggested the scale acceptability is $0.00-0.29=$ Weak; $0.30-0.69=$ Moderate and $0.70-$ $1.00=$ Strong. The result for reliability test for this study show in Table 7 below;

Table 7: Cronbach's Alpha for Each Criteria and Features of the i-KProM Questionnaire

Variables (Number of Item) Interpretation

Alpha Value

\begin{tabular}{llc}
\hline Sustainable Food Processing Practices & 0.73 & Strong \\
(After Factor Analysis) & & \\
i. $\quad$ Processing & (12) 0.81 & Strong \\
ii. $\quad$ Post-processing & (6) 0.50 & Moderate \\
iii. $\quad$ Pre-processing & (5) 0.57 & Moderate
\end{tabular}

Predictive Factors

\begin{tabular}{llcc} 
i. & Knowledge & (28) 0.75 & Strong \\
ii. & Awareness & $(10) 0.92$ & Strong \\
iii. & Attitude & $(13) 0.93$ & Strong \\
iv. & Subjective Norm & (4) 0.83 & Strong \\
v. & Perceived Behavioural Control & (6) 0.86 & Strong \\
vi. & Personal Norm & (3) 0.66 & Moderate \\
\hline
\end{tabular}

Conclusion and Recommendation

The i-KProM have been chosen to determine the sustainable food processing practices among 
the TVET students. This study is significant for the future of sustainable food production and consumption (SDG 2030). The validity and reliability aspects of the i-KProM were proven and being used to measure the adequacy of the sustainable food processing instrument.

There are six succeeded criteria of the i-KProM for sustainable food processing which is all criteria produce moderate to high reliability Cronbach alpha, $\alpha>0.50$ to 0.93 . The result of EFA for sustainable food processing practices remained 23 items that contribute to three factors which is; processing ( 12 items), post-processing ( 6 items) and pra-processing ( 5 items). The predictive factor variables consisted of 23 items which is; awareness (10 items), attitude (13 items), subjective norm (4 items), perceived behavioural control ( 6 items) and personal norm ( 3 items). Furthermore, data encompassing this study were suitable to run the EFA based on descriptive analysis.

Most of the research regarding the sustainable food processing only focusing on industrial and household sustainable practices (Ng \& Shukor, 2016: Ahamad et al., 2018) and limited articles related to sustainable food processing in TVET. Therefore, this instrument (iKProM) gives an advantage to the policy maker and management of TVET to review their curricular also policy regarding this issue which can contribute to educate our future sustainable practitioner in the food processing field.

\section{Acknowledgement}

This paper is a part of dissertation sponsored by Ministry of Higher Education Scholarship Programme.

\section{Corresponding Author}

Dr Suriani Mohamed

Universiti Pendidikan Sultan Idris, Malaysia

Email: suriani.mohamed@ftv.upsi.edu.my

\section{References}

Ahamad, N. R., \& Ariffin, M. (2018). Assessment of knowledge, attitude and practice towards sustainable consumption among university students in Selangor, Malaysia. Sustainable Production and Consumption, (1-11), S235255091830023X-. doi:10.1016/j.spc.2018.06.006.

Ahmad, H. (2004). Pengukuran kecergasaan motor. Tanjong Malim: Quantum.

Ahmad, J. H., Mustafa, H., \& Abdul Hamid, H. A., Wahab, J. A. (2011). Pengetahuan, sikap dan amalan masyarakat Malaysia terhadap isu alam sekitar. AKADEMIKA : Jurnal Sains Kemasyarakatan Dan Kemanusiaan, 81(3), 103-115.

Ajzen, I. (1991). The theory of planned behavior. Organizational behavior and human decision processes, 50(2), 179-211.

Alders, R. G., Ratanawongprasat, N., Schönfeldt, H., \& Stellmach, D. (2018). A planetary health approach to secure, safe, sustainable food systems: workshop report. Food Security, 10(2), 489-493. https://doi.org/10.1007/s12571-018-0780-9.

Ali, M. H., \& Suleiman, N. (2016). Sustainable food production: Insights of Malaysian halal small and medium sized enterprises. International Journal of Production Economics, 181, 303-314. doi:10.1016/j.ijpe.2016.06.003. 
Aschemann-Witzel, J., de Hooge, I., Amani, P., Bech-Larsen, T., \& Oostindjer, M. (2015). Consumer-related food waste: Causes and potential for action. Sustainability (Switzerland), 7(6), 6457-6477. https://doi.org/10.3390/su7066457

Augustin, M. A., Riley, M., Stockmann, R., Bennett, L., Kahl, A., Lockett, T., Cobiac, L. (2016). Role of food processing in food and nutrition security. Trends in Food Science and Technology, 56, 115-125. https://doi.org/10.1016/j.tifs.2016.08.005.

Aziz, A. N. A., Musa, D., \& Rashid, R. (2019). Entrepreneurial Intention among TVET Students: Examining the Relationship with the Individual Entrepreneurial Orientation. 9th National Conference in Education - Technical \& Vocational Education and Training (CIE-TVET) 2019, 483-495.

Ball, H. L. (2019). About Research: Conducting Online Surveys. Journal of Human Lactation, 089033441984873 . doi:10.1177/0890334419848734.

Besar, T. A., Hassan, M. S. H., Bolong, J., \& Abdullah, R. (2013). Exploring the levels of knowledge, attitudes and environment-friendly practices among young civil servants in Malaysia. Pertanika Journal of Social Science and Humanities, 21(July), 21-38.

Brown, J. D. (2009) Choosing the Right Type of Rotation in PCA and EFA. Shiken: JALT Testing and Evaluation SIG Newsletter, 13, 20-25.

Callegaro, M., Manfreda, L. K., \& Vehovar, V. (2015). Web Survey Methodology. London: Sage Publications.

Cavana, R. Y., Delahaye, B. L., \& Sekaran, U. (2001). Applied Business Research: Qualitative And Quantitative Methods. Milton, Old: John Wiley \& Son Australia.

Chin, C. K., Munip, H., Miyadera, R., Thoe, N. K., Ch'ng, Y. S., \& Promsing, N. (2019). Promoting Education for Sustainable Development in Teacher Education integrating Blended Learning and Digital Tools: An Evaluation with Exemplary Cases. Eurasia Journal of Mathematics, Science and Technology Education, 15(1), em1653. https://doi.org/10.29333/ejmste/99513.

Derahim, N., Hashim, H. S., \& Ali, N. (2011). Tahap Kelestarian Pelajar Universiti Kebangsaan Malaysia ke Arah Kampus Lestari. Jurnal Personalia Pelajar, 14, 1-10. https://doi.org/10.1016/j.ultrasmedbio.2011.05.669

Etse, D., \& Ingley, D. (2016),"Higher education curriculum for sustainability", International Journal of Sustainability in Higher Education, Vol. 17 Iss 2 pp. 269 - 280. http://dx.doi.org/10.1108/IJSHE-07-2015-0121.

Fincham, J. E. (2008). Response Rates and Responsiveness for Surveys, Standards, and the Journal. American Journal of Pharmaceutical Education, 72(2), 43. doi:10.5688/aj720243.

Garnett, T. (2013). Food sustainability: Problems, perspectives and solutions. Proceedings of the Nutrition Society, 72(1), 29-39. https://doi.org/10.1017/S0029665112002947.

Gössling, S., Garrod, B., Aall, C., Hille, J., \& Peeters, P. (2011). Food management in tourism: Reducing tourism's carbon "foodprint." Tourism Management, 32(3), 534-543.

Gunders, D., \& Bloom, J. (2017). Wasted: How America is losing up to 40 percent of its food from farm to fork to landfill. Natural Resources Defense Council. https://www.nrdc.org/resources/wasted-how-america-losing-40-percent-its-foodfarm-fork-landfill on $22^{\text {nd }}$ June 2020

Greyson, D. L., \& Johnson, J. L. (2016). The role of information in health behavior: A scoping study and discussion of major public health models. Journal of the Association for Information Science and Technology, 67(12), 2831-2841. 
Gurudasani, R., \& Sheth, M. (2009). Food safety knowledge and attitude of consumers of various food service establishments. Journal of Food Safety, 29(3), 364-380.

Hungerford, H. R., \& Volk, T. L. (1990). Changing learner behavior through environmental education. The Journal Of Environmental Education, 21(3), 8-21.

Jabatan Pendidikan Politeknik dan Kolej Komuniti, JPPKK. (2018). Rangka Kerja TVET 4.0. Putrajaya. Malaysia. From https://www.mypolycc.edu.my/index.php/muatturun/penerbitan/download/2-penerbitan/110-rangka-kerja-tvet-4-0-2018-2025 on 14th June 2020

Jabatan Pendidikan Politeknik dan Kolej Komuniti, JPPKK. (2020). Program Sijil Yang Ditawarkan Di Kolej Komuniti. https://www.mypolycc.edu.my/index.php/program/sepenuh-masa/sijil. On $22^{\text {nd }}$ June 2020.

Jackson, S. L. (2006). Research Method for Statistics. Thomson Wadsworth.

Kline, R. B. (2005). Principles and Practice of Structural Equation Modeling (2nd ed.). New York: Guilford. 366, ISBN 978-1-57230-690-5.

Knorr, D., Augustin, M. A., Tiwari, B. (2020). Advancing the Role of Food Processing for Improved Integration in Sustainable Food Chains. Frontiers in Nutrition, 7(), 34-. doi:10.3389/fnut.2020.00034

Kollmuss, A., \& Agyeman, J. (2002). Mind the Gap: Why do people act environmentally and what are the barriers to pro-environmental behavior? Environmental Education Research, 8(3), 239-260. doi:10.1080/13504620220145401 Lilley, D. (2009). Design for sustainable behaviour: strategies and perceptions. Design Studies, 30(6), 704720. https://doi.org/10.1016/j.destud.2009.05.001.

Madden, T. J., Ellen, P. S., \& Ajzen, I. (1992). A comparison of the theory of planned behavior and the theory of reasoned action. Personality and Social Psychology Bulletin, 18, 39.

Malaysian Qualification Agency. (2019). Code of Practices for TVET Programme Accreditation. Cyberjaya.

Mahat, H., Pasang. D., Hashim, M., Saleh, Y., \& Nayan, N (2019). Amalan Rendah Karbon dalam Kalangan Isi Rumah. Journal Of Techno Social VOL. 11 NO. 1 (2019) 29-38. DOI: https://doi.org/10.30880/jst.2018.11.01.004.

$\mathrm{Ng}, \mathrm{G} . \mathrm{K} .$, \& Shukor, S. A. (2016). Sustainability in food processing industry: An overview. Advanced Science Letters, 22(7), 1835-1839.

Nasir, R. A. (2020). Kesahan dan Kebolehpercayaan Instrumen Kelestarian Pemprosesan Makanan (i-KProM) dalam Pendidikan Teknikal dan Vokasional. e-Proceedings of the National Technology Research in Engineering, Design and Social Science Conference (nTrends'20) pp. 442-450.

Martindale, W., \& Schiebel, W. (2017). The impact of food preservation on food waste. British Food Journal, 119(12), 2510-2518. https://doi.org/10.1108/BFJ-02-2017-0114

Ofstad, S., Westly, L., Bratelli, T. (1994). Norway, miljøverndepartementet, symposium on sustainable consumption. In: Symposium: Sustainable Consumption: 19-20 January 1994: Oslo, Norway. Ministry of Environment, Oslo, Norway.

Okumus, B. (2019): How do hotels manage food waste? evidence from hotels in Orlando, Florida, Journal of Hospitality Marketing \& Management. DOI: 10.1080/19368623.2019.1618775. 
Omar, M., Payus, C. M., \& Vun, L. W (2019). Tahap Celik Alam Sekitar Dalam Kalangan Pelajar Tingkatan Lima di Sabah. Malaysian Journal of Social Sciences and Humanities, Volume 4, Issue 1, (page 41 - 49).

Pallant, J. (2016). SPSS Survival Manual: A step by step guide to data analysis using SPSS for windows (Version 15) (6th ed.). McGraw-Hill House.

Paryono. (2017). AIP Conference Proceedings [Author(s) Green Construction And Engineering Education For Sustainable Future: Proceedings of the Green Construction and Engineering Education (GCEE) Conference 2017 - East Java, Indonesia (8-9 August 2017)] - The importance of TVET and its contribution to sustainable development. , 1887(), 020076-. doi:10.1063/1.5003559.

Pett, M. A., Lackey, N. R., \& Sullivan, J. J. (2003). Making sense of factor analysis: The use of factor analysis for instrument development in health care research. Thousand Oaks, California: Sage.

Raman, F. I., \& Bakar, K. A. (2019). Amalan kelestarian alam sekitar dalam kalangan guru prasekolah (Environmental sustainability practices among preschool teachers). Geografia-Malaysian Journal of Society and Space, 15(2).

Ramly, Z., Hashim, N. H., Yahya, W. K., \& Mohamad, S. A. (2012). Tingkah Laku Keprihatinan Terhadap Alam Sekitar dalam Kalangan Pengguna Malaysia: Satu Analisis Empirikal. Jurnal Pengurusan 35(2012) $111-121$.

Retno, B., Nawasiah, N., \& Hilmiyah, N. (2019). Dalam Membangunkan Kelestarian (Value and Behaviors Of Green Consumption In Sustainability Development). 1(2), 30-38.

Reza, M. I. H. (2016). Sustainability in higher education: Perspectives of Malaysian higher education system. SAGE Open, 6(3). https://doi.org/10.1177/2158244016665890.

Ruolin, E. M., \& Nicolette, L. C. (2020): The role of gender, race, and ethnicity in environmental identity development in undergraduate student narratives, Environmental Education Research, DOI: 10.1080/13504622.2020.1717449.

Rus, R. C., Husain, M. A. M., Hanapi, Z., \& Mamat, A. B. (2020). TVETagogy: Teaching and Facilitating Framework (PDPC) for Technical and Vocational Education and Training (TVET). International Journal of Academic Research In Business And Social Sciences, 10(3).

Salas-Zapata, W. A., Ríos-Osorio, L. A., \& Cardona-Arias, J. A. (2018). Knowledge, Attitudes and Practices of Sustainability: Systematic Review 1990-2016. Journal of Teacher Education for Sustainability, 20(1), 46-63. https://doi.org/10.2478/jtes-2018-0003

SDG. (2030). Incheon Declaration and Framework for Action for the implementation of Sustainable Development Goal 4. Incheon.

Tabachnick, B. G., \& Fidell, L. S. (2013). Using multivariate statistics (6th ed.). Pearson: Boston. Taufique, K. M. R., Siwar, C., Chamhuri, S. F. H. (2016). Integrating General Environmental Knowledge and Eco-Label Knowledge in Understanding Ecologically Conscious Consumer Behavior. Procedia Economics and Finance, 37(), 39-45. doi:10.1016/s2212-5671(16)30090-9

Tseng, M.-L., Divinagracia, L., and Divinagracia, R. (2009). Evaluating firm's sustainable production indicators in uncertainty. Computers \& Industrial Engineering, Vol. 57 No. 4, pp. 1393-1403.

Tuten, T. L. (2010). Conducting Online Surveys. Advanced Methods for Conducting Online Behavioral Research. American Psychological Association (APA) Publication, 179-192.

UNESCO (2016). Recommendation Concerning Thecnical and Vocational Education Training. France. 
INTERNATIONAL JOURNAL OF ACADEMIC RESEARCH IN BUSINESS AND SOCIAL SCIENCES

Vol. 11, No. 4, 2021, E-ISSN: 2222-6990 @ 2021 HRMARS

Wahyudi, T., Warijan, W., \& Suyanta, S. (2020). The Ulitilization Of On-line Exams On Health Polytechnic Students. Systematic Reviews in Pharmacy, 11(5), 683-687. 